\title{
$\overline{\underline{\mathrm{R}} \underline{\underline{\perp B}}}$
}

\section{Does Problem-Based Learning Affect Students' Speaking Skill and Attitude toward ELL?}

\author{
Gede Sutrisna $^{* 1}$ and Luh Putu Artini ${ }^{2}$ \\ ${ }^{1}$ Universitas Dwijendra \& ${ }^{2}$ Universitas Pendidikan Ganesha, Indonesia \\ *gedesutrisna@undwi.ac.id
}

\begin{tabular}{l}
\hline Received: 27/08/2020 $\quad$ Revised: 20/10/2020 \\
\hline How to cite (in APA style): \\
$\begin{array}{l}\text { Sutrisna, G., Artini, L, P. (2020). Does Problem Based Learning Affect Students' Speaking Skill and Attitude toward ELL? } \\
\quad \text { Retorika: Jurnal Ilmu Bahasa, 6(2), 131-138. doi: https://doi.org/10.22225/jr.6.2.2315.131-138 }\end{array}$ \\
\hline
\end{tabular}

\begin{abstract}
As a typical learning method which is grounded from a scientific approach, problem-based learning (PBL) does not only enhance students' critical thinking but also helps them actively construct their knowledge and skill. The objectives of this study were to investigate the impact of PBL on (1) students' speaking skill and (2) their attitude toward ELL. This study employed an embedded mixed-method design which combined onegroup pretest-posttest and descriptive qualitative design. It involved a group of 41 students as the sample. The quantitative data were collected through pretest-posttest and questionnaire (closed-ended). Meanwhile, the qualitative data were obtained through observation and open-ended questionnaire. The findings of the study found that students demonstrated better speaking performance after being treated through PBL activities. Besides, they exhibited more positive behavioral, cognitive, and affective attitude toward ELL.
\end{abstract}

Keywords: Attitude, English language learning, Problem-Based Learning, Speaking Skill

\section{INTRODUCTION}

Practically, teaching and learning are parts of the most prominent elements in education. The knowledge is transferred through the teaching process from teachers to students. Then, the knowledge itself is acquired by the students through the learning process. As the agent of teaching, teachers probably have the primary role in the educational process since they directly organize students' learning experiences (Guadalupe, 2010). They also hold a great responsibility to lead and involve the students in learning process so that they can achieve the learning objectives effectively. However, carrying out such great responsibility is not an easy task. Every aspect of the teaching and learning process should be taken into deep consideration. One of the aspects which may bring an enormous influence to the students' learning is teaching approach. Teachers should select and apply appropriate teaching approach in order to facilitate the process of knowledge transmission effectively (Ganyaupfu, 2013). With the appropriate selection and application of teaching approach, teachers could fit students' learning demand and help them to accomplish their learning objectives. Among the existing teaching approaches, scientific approach has been claimed to bring lots of benefits for learners (Ministry of Education and Culture, 2013).

The scientific approach derives from constructivism which is about how people learn. Jurković (2005) stated that constructivism is a philosophy based on the fundamental assumption that knowledge cannot exist outside 
our minds. Knowledge cannot be given from one mind to another. Thus, new knowledge is built or created from within the individual through experience. Therefore, it is very important for teachers to understand and adopt this new philosophy and to provide opportunities for students to create new knowledge. This philosophy of constructivist pedagogies implies that learners are required to construct knowledge by themselves. Learners are considered as important agents in the learning process. They are expected to learn actively through cognitive processes, building an understanding of the world around them. Therefore, in a constructivist perspective, students themselves directly develop knowledge by experiencing various things and by reflecting on these experiences (Har, 2005).

Scientific approach is currently integrated into the implementation of Indonesian latest curriculum, Curriculum 2013. Having the characteristic of "doing science", it is hoped that the use of this approach can enable teachers to promote student learning by breaking the process into steps containing detailed instructions (Zaim, 2017). The purpose is to help students develop their skills, enhance their oral communication and critical thinking, as well as promote a positive attitude toward learning (Kartikawati, 2015)

Technically, the application of the scientific approach in the teaching and learning process can be carried out with three learning methods. Those methods are Discovery Learning, Project-based learning, and Problem-based learning. In accordance with its fruitful benefits, our latest curriculum, Curriculum 2013 suggests ProblemBased Learning (PBL) as one of the applicable approaches in the teaching learning process. According to Jurković (2005), PBL enables the learners to develop their critical thinking since they are required to solve the assigned problems during the process of learning. The use of this method also helps them possess good collaboration skills. During PBL activities, learners engage in a group discussion and work collaboratively to identify the solution toward the presented problem (Westwood, 2008).

Besides, Hmelo-Silver (2004) believes that PBL provides students the opportunity to consider how the facts they obtain relate to a particular problem at hand. They integrate information across multiple domains to which it can be easily and flexibly applied under various and appropriate circumstances. This process helps them become reflective and flexible thinkers who can use knowledge to take action. In PBL, the role of the teacher is not to provide knowledge, but to facilitate and encourage the students to engage in self-directed learning (SDL) and collaborative working. During problem-solving activities, students work in small collaborative groups and learn what they need to know in order to solve a problem. Concerning SDL, students actively explore the learning resources, employ strategies, and construct knowledge. Then, they apply their knowledge to the problem and reflect on what they learned and the effectiveness of the strategies employed. These learning processes practically help the students become active learners and make them responsible for their own learning so that they do not rely on their teachers as the main source of knowledge.

Yet, the result of the preliminary classroom observation indicated that the teacher seemed to be convenient with traditional teaching which did not apply the principles of PBL. The way they used the teacher-centered approach was noticed to affect the students become passive and dependent learner as the teacher dominated the teaching and learning process. Instead of showing active participation, they merely acted as the recipients of teachers' knowledge. As the result, they were not able to develop their skills productively. Besides, the learning activities provided by the teacher seemed to fail to obtain students' learning enthusiasm. This might affect their attitude while participating the teaching and learning process or it might even influence their attitude toward the lesson itself.

The implementation of PBL is assumed to be the appropriate solution for those issues. A number of studies have confirmed for its effectiveness in teaching and learning process. Yuda et al. (2016) found that problem-based learning (PBL) has a significant effect on students' speaking competency. It encourages the students to actively participate in finding the solution toward the problems. In addition, she revealed that the implementation of $\mathrm{PBL}$ is effective to enhance students' speaking competence, more particularly for the fielddependent ones. Ansarian et al. (2016) revealed that the implementation of PBL through cognition-based tasks significantly increased 
intermediate Iranian intermediate EFL learners' speaking proficiency. Another research was conducted by Mufaidah (2014) with aim to determine the effects of problem-based learning (PBL) on students' speaking skill. Her research was conducted at SMPN 1 Atap Bandungan which involved 30 students of 8th grade as the participants. The result of her research revealed that the use of PBL was able to enhance students' speaking skill. Besides it promoted students' activeness, motivation as well as their vocabulary mastery. Other researchers, Keong \& Mohammed (2015) found that the implementation of PBL was able to improve the speaking skill of Iraqi high school students and motivate them towards better language achievement. The improvement was specifically found in terms of pronunciation, vocabulary, fluency and grammar. Then, the other researchers, Demirel \& Dağyar (2016) did a meta-analysis study to determine the effects of PBL on students' attitudes as compared to traditional teaching. The result of their study revealed that PBL has a low positive effect on students' attitude. It indicated that PBL is effective in helping students gain a positive attitude toward courses.

Considering the significances of PBL, this research is purposely conducted to investigate the impact of PBL on students' speaking skill and attitude toward English language learning (ELL) involving the behavioral, cognitive, and affective aspects of attitude. Due to the fact that this present research is the continuation of the previous research $(\mathrm{R} \& \mathrm{D})$, the products in form of PBL instructional materials for teaching English in grade seven developed by Darmawan et al. (2016) were used to facilitate this research. Those developed instructional materials, which have been verified for its relevance, were implemented and observed for the impact.

\section{METHODS}

The design of this study was an embedded mixed-method which combined onegroup pretest-posttest and descriptive qualitative design. This design involves both quantitative and qualitative data collection, but one type of data plays an additional role in the overall design (Creswell and Clark, 2006). This study involved 41 seventh grade students of secondary public school in Denpasar, Bali. The data collection was facilitated by using four types of instruments including observation checklist, speaking test, questionnaire (closed and open-ended types). The observation checklist was used to investigate whether the teacher had implemented problem-based learning instruction in the teaching and learning process prior to the treatment.

In this study, the questionnaire was developed from the theories of Wenden (1991) which involve three aspects of attitudes, i.e., behavioral, cognitive, affective or emotional. It was further constructed into two types, i.e., open-ended and the combination of closed and open-ended. Regarding the design of this research, the collected data were analyzed both quantitatively and qualitatively. The analysis of the quantitative data involved the result of pretest and post-test as the measurement of students' speaking skills, as well as the questionnaire of students' attitude (closed-ended type). The collected data were then descriptively analyzed in term of mean, median, range, variance, and standard deviation. Besides, paired sample t-test was specifically executed as further statistical analysis to investigate the impact of PBL on students' speaking skills and their attitude toward ELL. For the sake of efficiency and accuracy, the execution for the entire statistical analyses was assisted by IBM SPSS ver.23 for windows.

Meanwhile, the qualitative data of this research were obtained from the observation checklist, field notes, and open-ended questionnaire. The collected data were then analyzed through three concurrent flows of activities including data reduction, data display and conclusion drawing/verification proposed by (Miles \& Huberman, 1994).

\section{RESULTS AND DISCUSSION}

\section{The Impact of PBL on Students' Skills}

From the result of data analysis in the pretest, it was revealed that the mean score for students' speaking, in general was 57.61 (SD = 11.135). Considering the generated mean score, it could be assumed that students possessed low speaking skills. After the treatment, it was revealed that the mean score for speaking, in general was $77.27(\mathrm{SD}=9.341)$. It was higher and considered to have an improvement compared to the result before the study. Furthermore, it was supported by the result of 
paired sample t-test with t-value of $-25.833(\mathrm{P}=$ $.000<.05)$, indicating that there was a statistically significant difference in students' speaking skills before and after the implementation of PBL.

Specifically, the improvement was also found in students' dialogue and monologue performance. As displayed in Table 1, it was revealed that the mean score of students' monologue performance in the pre-test was $53.66(\mathrm{SD}=10.544)$. The lowest score achieved by the student was 32 ; meanwhile, the highest was 76. Then, the mean score of students' monologue performance after the treatment was 73.85 (SD = 9.385). The lowest score achieved by the student was 56 ; meanwhile, the highest was 92 . Those achievements obviously pointed out that there was an improvement in students' monologue performance.

Table 1

Pre- and Post-Test Scores for Students' Monolog Performance

\begin{tabular}{lcc}
\hline & $\begin{array}{c}\text { Monolog } \\
\text { (pre-test) }\end{array}$ & $\begin{array}{c}\text { Monolog } \\
\text { (post-test) }\end{array}$ \\
\hline Mean & 53.66 & 73.85 \\
\hline $\begin{array}{l}\text { Std. } \\
\text { Deviation }\end{array}$ & 10.544 & 9.385 \\
\hline Maximum & 76 & 92 \\
\hline Minimum & 32 & 56 \\
\hline
\end{tabular}

Then, from Table 2's legend, it was noticed that the mean score of students' dialogue performance before the treatment was $61.56(\mathrm{SD}=10.388)$. The lowest score achieved by the student was 40 ; meanwhile, the highest was 84. After the treatment, it was figured out that the mean score of students' dialogue performance was $80.68(\mathrm{SD}=8.045)$. The lowest score achieved by the student was 64 ; meanwhile, the highest was 96. Compared to the achievement before the treatment, these achievements were considered to have improvement.

Table 2

Pre- and Post-Test Scores for Students' Dialog Performance

\begin{tabular}{lcc}
\hline & $\begin{array}{c}\text { Monolog } \\
\text { (pre-test) }\end{array}$ & $\begin{array}{c}\text { Monolog } \\
\text { (post-test) }\end{array}$ \\
\hline Mean & 61.56 & 80.68 \\
\hline $\begin{array}{l}\text { Std. } \\
\text { Deviation }\end{array}$ & 10.388 & 8.045 \\
\hline Maximum & 84 & 96 \\
\hline Minimum & 40 & 64 \\
\hline
\end{tabular}

The effect of PBL on both students' monolog and dialog performance was also confirmed by the result of paired sample t-test. As displayed in Table 3, for students' dialog performance, $\mathrm{t}=-17.314$ and $\mathrm{P}=.000<.05$, and for students' monolog performance $\mathrm{t}=-19.158$ and $\mathrm{P}=.000<.05$

Table 2

Paired Sample T-Test for Students' Monolog and Dialog Performance Before and After the Treatment

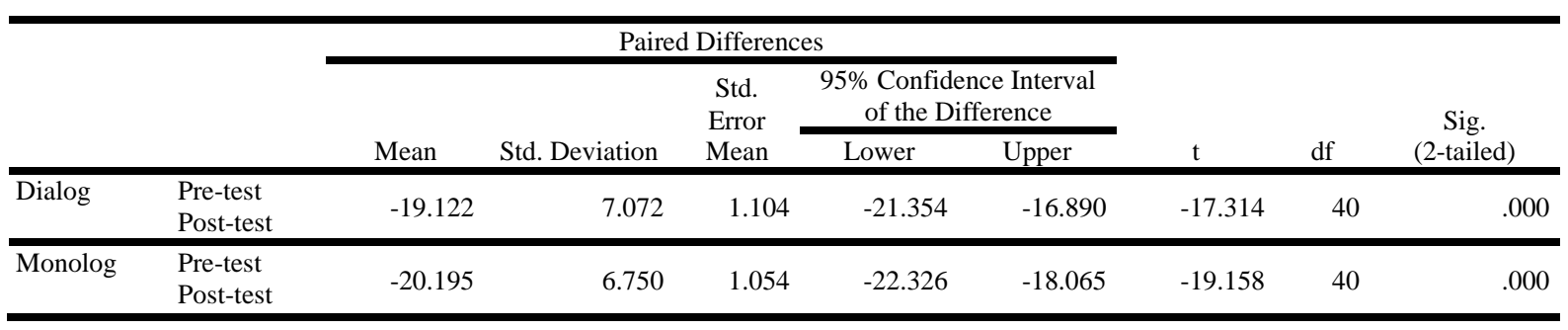

Overall, these findings indicated that the implementation of PBL could enhance students' speaking skills, more particularly in terms of dialogue and monologue performance. Problems were found to effectively encourage the students to have active and communicative participation during the problem-solving activities, as claimed by Yuda et al. (2016). As the students actively demonstrate verbal interaction during PBL activities, their speaking skills will be developed. In addition, Surif et al. (2013) state that PBL enables the students to develop their speaking skills as they share ideas and actively communicate it with the other partners to form new ideas during having group discussion or presentation session. In line with Surif et al. 
(2013), Mulya, Adnan, \& Ardi (2013) assert that students could practice their speaking skills during group interaction in which they could deliver their ideas or express their opinions with the other group members.

\section{The Impact of PBL on Students' Attitude toward English Language Learning}

In accordance with the findings on students' attitude, PBL was statistically proven to bring significant impact on students' attitude toward English language learning (ELL). It could be seen from the improvement of students' attitude mean score after having PBL activities. From Table 4's legend, prior to the implementation of PBL, the mean score of students' attitude was $3.52(\mathrm{SD}=0.392)$. It improved into $4.49(\mathrm{SD}=0.293)$ after the treatment.
Table 3

Students' Attitude Mean Scores Before and After Treatment

\begin{tabular}{ccc}
\hline \multicolumn{1}{c}{ Phase } & Mean & Std. Deviation \\
\hline Before treatment & 3.52 & 0.392 \\
\hline After treatment & 4.49 & 0.293 \\
\hline
\end{tabular}

Such an improvement was further verified with the result of paired sample t-test (See Table 5). For students' attitude in general, the results, $t$ $=-13.906$ and $\mathrm{P}=.000<.05$ indicated that there were significant differences on students' attitudes toward English language learning (ELL) before and after the implementation of PBL. Considering those findings, it could be inferred that PBL successfully enables the students to exhibit a better and more positive attitude toward ELL.

Table 4

Paired Sample T-Test for Students' Attitude Before and After Treatment

\begin{tabular}{|c|c|c|c|c|c|c|c|c|}
\hline & \multicolumn{5}{|c|}{ Paired Differences } & \multirow[b]{3}{*}{$\mathrm{t}$} & \multirow[b]{3}{*}{ df } & \multirow{3}{*}{$\begin{array}{c}\text { Sig. } \\
\text { (2-tailed) }\end{array}$} \\
\hline & \multirow[b]{2}{*}{ Mean } & \multirow[b]{2}{*}{ Std. Deviation } & \multirow{2}{*}{$\begin{array}{c}\text { Std. } \\
\text { Error } \\
\text { Mean }\end{array}$} & \multicolumn{2}{|c|}{$\begin{array}{l}95 \% \text { Confidence Interval } \\
\text { of the Difference }\end{array}$} & & & \\
\hline & & & & Lower & Upper & & & \\
\hline $\begin{array}{l}\text { Students' attitude before } \\
\text { and after treatment }\end{array}$ & -.973 & .448 & .070 & -1.115 & -.832 & -13.906 & 40 & .000 \\
\hline
\end{tabular}

Then, as it could be seen in Table 6, their attitudes, more particularly in term of behavioral, cognitive, and affective aspects, exhibited significant improvement as well. The mean scores of those three aspects of attitude after the implementation of PBL highly improved in comparison with its mean scores before treatment.

Table 5

Data of Students' Attitude in terms of Behavioral, Cognitive, and Affective Aspects

\begin{tabular}{llll}
\hline Phase & Aspect & Mean & $\begin{array}{l}\text { Std. } \\
\text { Deviation }\end{array}$ \\
\hline \multirow{2}{*}{$\begin{array}{l}\text { Before } \\
\text { treatment }\end{array}$} & Behavioral & 3.45 & 0.408 \\
\cline { 2 - 4 } & Cognitive & 3.52 & 0.438 \\
\cline { 2 - 4 } \multirow{2}{*}{$\begin{array}{l}\text { After } \\
\text { treatment }\end{array}$} & Affective & 3.59 & 0.394 \\
\cline { 2 - 4 } & Behavioral & 4.46 & 0.313 \\
\cline { 2 - 4 } & Cognitive & 4.56 & 0.256 \\
\hline
\end{tabular}

Firstly, the mean score of students' attitude in term of affective aspect statistically improved after being involved in PBL activities ( $\mathrm{M}=4.49$, $\mathrm{SD}=0.359)$ in comparison with its earlier achievement $(\mathrm{M}=3.59, \mathrm{SD}=0.394)$. Their feedbacks which were obtained from the openended questionnaire confirmed such a positive transformation on their attitude. Fifteen students (36.59\%) were highly excited; 21 students $(51.22 \%)$ felt excited; and then 2 students $(4.88$ $\%)$ were quite excited with the provided problembased learning activities in their English teaching and learning process. This meant that PBL successfully affected the majority of them to have the better affective attitude toward English language learning (ELL) since it could bring them such a learning excitement during the English teaching and learning process. Due to having such a learning excitement, their willingness to learn English increased as well, as cited from the following representative comment.

Excerpt 1: (S1-M) 
"Saya merasakan pembelajaran ini sangat menyenangkan sehingga membuat saya semakin tertarik dengan pelajarannya"

[I found the teaching and learning process were highly enjoyable so that I was getting more motivated to learn more]

Deriving from these findings, it could be inferred that PBL implementation allows the students to have a positive affective or emotional attitude toward ELL.

Secondly, the mean score of students' attitude in term of the cognitive aspect after having PBL activities statistically showed a significant improvement $(\mathrm{M}=4.56, \mathrm{SD}=$ 0.256 ). Retrieved from their feedbacks on the open-ended questionnaire, it was found that students exhibited more positive viewpoints regarding to the implementation of PBL in the English teaching and learning process, indicating that they have the more positive cognitive attitude. Among 41 students, 25 students $(60.98 \%)$ implied that they could enjoy PBL activities in the English teaching and learning process since the researcher provided it attractively without making them bored. Then, 4 students $(9.76 \%)$ admitted that they enjoyed working in groups during the implementation of problem-based learning as cited from one of the representative feedback.

\section{Excerpt 2: (S3-M)}

"Menyenangkan karna belajar kelompok, jadi bisa saling bantu memahami materi pelajaran jika kurang mengerti"

[The teaching and learning process was exciting since I could have collaborative learning. Thus, we could help each other understand the learning material in case of lacking in understanding]

Regarding to their claim, collaborative working allowed them to have their group members' assistances in case of lacking in understanding. From such a claim, it could be implied that collaborative working facilitated them to have better learning because the knowledge acquisition comes through the process of exchanging and sharing the ideas within the group members.

Then, the rest 11 students $(26.83 \%)$ stated that the conducted problem-based learning activities were comprehensible and more appealing for them to learn. They also claimed that the researcher's clear instructions and facilitative teaching not only enhance their comprehension toward the learning material but also their learning motivation. Due to having a better understanding, they were revealed to be more motivated to learn English as cited from the following representative feedbacks.

\section{Excerpt 3: (S7-F)}

"Saya sangat senang karena Mr. D (peneliti) mengajar dengan santai, tenang, dan lucu. Cara mengajarnya sangat baik mampu membuat muridnya jadi mengerti."

[I am really excited because Mr. D (the researcher) is funny and easy-going. He teaches very well so that his students can understand his explanation.]

Excerpt 4: (S24-M)

"Materinya yang disampaikan oleh Mr. D (peneliti) mudah dimengerti sehingga saya lebih termotivasi lagi untuk belajar bahasa inggris"

[The learning material provided by $\mathrm{Mr} \mathrm{D}$ (the researcher) could be easily comprehended. It made me more motivated to learn English]

Deriving from those feedbacks, it could be inferred that PBL had effectively influenced the majority of students to have a better cognitive attitude toward English language learning (ELL). It fruitfully allowed them to develop their better understanding as well as language skills acquisition during English teaching and learning process.

Thirdly, having engaged through PBL process, students were noticed to show a more positive behavioral attitude. It was statistically represented by the improvement of its mean score of 4.46 with $\mathrm{SD}=0.313$ in comparison with the result prior to the implementation of PBL (M = $3.45, \mathrm{SD}=0.408)$. From the observation, it was found that students no longer felt anxious or afraid, but more relaxed when they were required to speak in English class. As one of the process of PBL activities, presentation session seemed to make them accustomed to using or speaking English confidently. In respect to these findings, it could be inferred that the implementation of PBL leads students to exhibit better behavioral attitude in a way more confident to convey their ideas orally.

Furthermore, their feedbacks on the openended questionnaire provided another positive behavioral attitude toward ELL. Eighteen students $(43.90 \%)$ asserted that they were eager to put their best efforts to develop their English 
language skills such as studying English harder, improving their understanding toward the English learning material, and being more discipline to do the tasks they are assigned to. Then, 9 students $(21.95 \%)$ were revealed to have a great willingness in learning vocabularies. Apparently, they perceived vocabulary to play a major role in developing their language skills. Seeing from their feedbacks, they were motivated to improve or enrich their vocabularies in order to be able to speak English fluently.

\section{Excerpt 5: (S17-F)}

"Saya ingin menambah pengetahuan kata-kata bahasa inggris agar bisa berbicara bahasa inggris dengan lebih lancar"

[I want to improve my vocabulary knowledge so that I can speak English more fluently]

The other 14 students (34.15\%) were obviously eager to put their best effort in order to develop their productive skills. They would get themselves to practice harder in English speaking. More particularly, some of these students even asserted that they wanted to learn about words' pronunciation in order to be able to speak English effectively.

Excerpt 6: (S9-F)

\section{"Cara mengucapkan bahasa inggris yang benar"}

[I want to learn how to pronounce English words correctly]

Based on the mentioned and elaborated findings, it could be inferred that the implementation of PBL has positively impacted students' attitude toward ELL in terms of their behavioral, cognitive, and affective aspects. Students showed better affective attitude since they had enjoyable learning experiences. They were revealed to enjoy having PBL activities in the English teaching and learning process. Then, they showed better cognitive attitude as they found PBL could enhance their understanding and develop their English knowledge during English teaching and learning process. Their positive behavioral attitude could be seen from their willingness to learn more about English in order to improve their English language skills.

There were four researches which supported this study even though those researches were not the same as this research. The similarity between this research and those researches was about investigating the impact or effect of PBL on students' attitude. The result of a study conducted by Demirel \& Dağyar (2016) that found the effectiveness of PBL in promoting students' positive attitude toward courses. Kazemi \& Ghoraishi (2012), in their study, also found that PBL affected students' attitude. However, they focused on investigating students' attitude toward mathematics, not ELL. Another researcher, Charif (2010) reported that students' attitude toward chemistry increased as they expressed a feeling of satisfaction during the learning cycle. Then, the other researchers, Hande et al. (2015) discovered that the use of PBL could help students gain a favorable attitude in the context of medical education.

\section{CONCLUSION}

The result of this research reveals that Problem-Based Learning (PBL) brings a significant impact on students' English speaking skills. Problems were found to trigger students' active discussion and interaction to identify and find a solution for the assigned problem. While they were interacting with each other, they indirectly practice and develop their oral communication skills (speaking skills). PBL was also revealed to allow the students to have a positive attitude toward English Language Learning (ELL) in terms of behavioral, cognitive, and affective aspects. In term of behavioral aspect, the students were more eager to learn the aspects of English since they wanted to improve their English language skills. In term of cognitive aspect, they admitted that they could have a better understanding and English knowledge acquisition. Students were also revealed to have a more positive affective attitude toward ELL since they enjoyed PBL activities in the English teaching and learning process. Furthermore, PBL influenced the English teaching and learning process. PBL activities had brought the students into a new distinctive experience of learning. It provided them with more enjoyable and challenging learning rather than their previous teaching and learning process. As part of PBL activities, collaborative learning was proven to allow them to learn together with their friends joyfully. Consequently, they more motivated to involve into any required learning activities. In addition, the process of working collaboratively could effectively enhance their understanding of the learning materials since they could exchange and share ideas with each other to solve assigned 
problems or tasks. Not only collaborative learning but also the researcher's facilitative role has enabled them to have a better understanding, learning motivation as well as a positive attitude toward English teaching and learning process. To their viewpoint, the way the researcher facilitated them in a patient and caring manner avoided them from being afraid to make mistakes and express their thoughtful ideas during the active discussion.

\section{REFERENCES}

Ansarian, L., Adlipour, A. A., Saber, M. A., \& Shafiei, E. (2016). The Impact of ProblemBased Learning on Iranian EFL Learners' Speaking Proficiency. Advances in Language and Literary Studies, 7(3), 84-94.

Charif, M. (2010). The Effects of Problem Based Learning in Chemistry Education on Middle School Students' Academic Achievement and Attitude. Lebanese American University.

Darmawan, R. W., Artini, L. P., \& Ratminingsih, N. M. (2016). Developing Problem-Based Instructional Materials with Character Insertion According to Curriculum 2013 for Grade Seven of Junior High School. Jurnal Pendidikan Dan Pembelajaran Bahasa Indonesia.

Demirel, M., \& Dağyar, M. (2016). Effects of Problem-Based Learning on Attitude: A Metaanalysis Study. EURASIA Journal of Mathematics, Science and Technology Education, 12(8).

Ganyaupfu, E. M. (2013). Teaching Methods and Students' Academic Performance. International Journal of Humanities and Social Science Invention, 2(9), 29-35.

Guadalupe, C. (2010). Teachers as Primary Agents of Educational Systems. Focal: Dialoge, Research, Solution.

Hande, S., Mohammed, C. A., \& Komattil, R. (2015). Acquisition of knowledge, generic skills and attitudes through problem-based learning: Student perspectives in a hybrid curriculum. Journal of Taibah University Medical Sciences, 10(1), 21-25.

Har, L. B. (2005). Constructivist Learning and Teaching. The Hong Kong Institute of Education.

Hmelo-Silver, C. E. (2004). Problem-Based Learning: What and How Do Students Learn? Educational Psychology Review, 16(3), 235266.

Jurković, V. (2005). Guide to Problem-Based Learning. Ljubljana: Slovene Association of LSP Teachers.

Kartikawati, Y. (2015). The implementation of scientific approach in teaching English at the eighth grade of SMP Muhammadiyah 10 Surakarta in 2014/ 2015 academic year: a naturalistic study. Journal of The Implementation of Scientific Approach in English Teaching.

Kazemi, F., \& Ghoraishi, M. (2012). Comparison of Problem-Based Learning Approach and Traditional Teaching on Attitude, Misconceptions and Mathematics Performance of University Students. Procedia - Social and Behavioral Sciences, 46, 3852-3856.

Keong, Y. C., \& Mohammed, A. H. (2015). Improving Iraqi Secondary Students' Speaking Performance through ProblemBased Learning Approach. International Journal of Education and Research, 3(2), 87-96.

Miles, M. B., \& Huberman, A. M. (1994). Qualitative Data Analysis: An Expanded Sourcebook (2nd Ed.). Thousand Oaks: Sage.

Ministry of Education and Culture. (2013). Diklat guru dalam rangka implementasi kurikulum 2013. Konsep pendekatan saintifik pada jenjang SD/SMP/SMA. Jakarta: Kementerian Pendidikan dan Kebudayaan.

Mufaidah, U. (2014). Problem Based Learning: Enhancing Students' Speaking Skill on The Second Students of SMPN 1 Atap Bandungan in the Academic Year 2013/2014. State Institute for Islamic Studies (STAIN) Salatiga.

Mulya, R. A., Adnan, A., \& Ardi, H. (2013). The Effect of Problem Based Learning Strategy Toward Students' Speaking Ability at the First Grade of SMAN 1 Enam Lingkung. Journal of English Language Teaching, 2(1), 314-323.

Surif, J., Ibrahim, N. H., \& Mokhtar, M. (2013). Implementation of Problem Based Learning in Higher Education Institutions and Its Impact on Students' Learning. In The 4th International Research Symposium on Problem-Based Learning (IRSPBL) 2013. Aalborg: Aalborg Universitetsforlag.

Wenden, A. (1991). Learner Strategies for Learner Autonomy. London: Prentice Hall.

Westwood, P. (2008). What Teachers Need to Know about Teaching Methods. Victoria: ACER Press.

Yuda, M. S., Seken, I. K., \& Ratminingsih, N. M. (2016). The Effect of Problem-Based Learning and Learning Styles on Speaking Competence of Tenth Grader in SMA Negeri 2 Tabanan. Universitas Pendidikan Ganesha.

Zaim, M. (2017). Implementing Scientific Approach to Teach English at Senior High School in Indonesia. Asian Social Science, 13(2), 33. 